\title{
a-Lipoic acid regulates AMP-activated protein kinase and inhibits insulin secretion from beta cells
}

Received: 15 October 2005 / Accepted: 27 February 2006 / Published online: 13 May 2006

C) Springer-Verlag 2006

\begin{abstract}
Aims/hypothesis: The antioxidant compound $\alpha$ lipoic acid $(\alpha-\mathrm{LA})$ possesses antidiabetic and anti-obesity properties. In the hypothalamus, $\alpha$-LA suppresses appetite and prevents obesity by inhibiting AMP-activated protein kinase (AMPK). Given the therapeutic potential of $\alpha$-LA for the treatment of type 2 diabetes and obesity, and the importance of AMPK in beta cells, we examined the effect of $\alpha$-LA on pancreatic beta cell function. Materials and methods: Isolated rat islets and MIN6 beta cells were treated acutely (15-90 min) or chronically (18-24 h) with $\alpha$-LA or the known AMPK-activating compounds 5'amino-imidazole-4-carboxamide ribonucleoside (AICAR) and metformin. Insulin secretion, the AMPK-signalling pathway, mitochondrial function and cell growth were assessed. Results: Acute or chronic treatment of islets and MIN6 cells with $\alpha$-LA led to dose-dependent rises in phosphorylation of the AMPK $\alpha$-subunit and acetyl CoA carboxylase. Chronic exposure to $\alpha$-LA, AICAR or metformin caused a reduction in insulin secretion. $\alpha$-LA inhibited the p70 s6 kinase translational control pathway, and inhibited MIN6 growth in a manner similar to rapamycin. Unlike AICAR and metformin, $\alpha$-LA also acutely inhibited insulin secretion. Examination of the effect of $\alpha$-LA on mitochondrial function showed that
\end{abstract}

E. D. Targonsky · F. Dai · V. Koshkin · G. T. Karaman

A. V. Gyulkhandanyan · Y. Zhang · M. B. Wheeler $(\triangle)$

Department of Physiology, University of Toronto,

1 King's College Circle,

Toronto, ON, Canada M5S 1A8

e-mail: michael.wheeler@utoronto.ca

Tel.: +416-978-1969

Fax: $+416-978-4940$

M. B. Wheeler

Department of Medicine, University of Toronto,

Toronto, ON, Canada

C. B. Chan

Department of Biomedical Sciences,

Atlantic Veterinary College,

University of Prince Edward Island,

PE, Canada acute treatment with this compound elevated reactive oxygen species (ROS) production and enhanced mitochondrial depolarisation induced by $\mathrm{Ca}^{2+}$. Conclusions/ interpretation: This study is the first to demonstrate that $\alpha$-LA directly affects beta cell function. The chronic effects of $\alpha$-LA include AMPK activation and reductions in insulin secretion and content, and cell growth. Acutely, $\alpha$-LA also inhibits insulin secretion, an effect probably involving the ROS-induced impairment of mitochondrial function.

Keywords AMPK · Insulin secretion $\cdot \alpha$-Lipoic acid · Mitochondrial permeability transition $\cdot \mathrm{mTOR} \cdot$ Pancreatic beta cell $\cdot$ Reactive oxygen species

Abbreviations $\alpha$-LA: $\alpha$-lipoic acid $\cdot \Delta \Psi_{\mathrm{m}}$ : Mitochondrial membrane potential - ACC: acetyl CoA carboxylase - AICAR: 5'-amino-imidazole-4-carboxamide ribonucleoside - AMPK: AMP-activated protein kinase . DCF: dichlorofluorescein - GSIS: glucose-stimulated insulin secretion - KRBH: Krebs-Ringer buffer with HEPES - MPT: mitochondrial permeability transition mTOR: mammalian target of rapamycin · p70 s6k: p70 s6 kinase $\cdot$ ROS: reactive oxygen species

\section{Introduction}

$\alpha$-Lipoic acid ( $\alpha$-LA) is a short-chain fatty acid that acts as a cofactor of enzymes involved in mitochondrial respiration [1]. Beneficial anti-oxidative properties for $\alpha$-LA have been described in several tissues, including the brain [2], kidney [3] and heart [4]. In recent years, evidence has accumulated suggesting that $\alpha$-LA has a wide range of benefits in the treatment of diabetes. Bitar et al. [5] demonstrated that $\alpha$-LA could partly ameliorate insulin resistance in type 2 diabetic rats, while others had reported additional antidiabetic effects in earlier rodent $[4,6]$, and human studies [7]. In vitro approaches have also shown that $\alpha$-LA can enhance glucose disposal in skeletal muscle [8] and adipocytes [9], and suppress hepatic gluconeogen- 
esis [10]. The exact molecular mechanisms responsible for these effects are currently not known.

AMP-activated protein kinase (AMPK) functions as an energy sensor in mammalian cells (reviewed in [11]). AMPK is a heterotrimeric enzyme that is activated by stress signals [12], such as an elevated intracellular AMP: ATP ratio. When AMP levels rise, the AMPK $\alpha$-subunit becomes phosphorylated and activated, leading to the suppression of anabolic processes, including protein and lipid synthesis. This is accompanied by an increase in ATPgenerating pathways, including the $\beta$-oxidation of fatty acids. AMPK mediates insulin-independent glucose uptake in skeletal muscle [13], suppresses glucose production from the liver [14], and is activated by the hormones leptin [15] and adiponectin [16], and the antidiabetic drug metformin [17]. As such, AMPK has attracted much attention as a potential target for diabetes therapy.

Recently, the properties of $\alpha$-LA were linked to AMPK in a report describing its ability to prevent obesity in rats [18]. $\alpha$-LA treatment reduced body weight and feeding and increased energy expenditure in these rodents. These effects were shown to be, at least in part, due to the ability of $\alpha$-LA to suppress AMPK activity in the hypothalamus. Injection of rats with $5^{\prime}$-amino-imidazole-4-carboxamide ribonucleoside (AICAR), an AMP analogue and potent activator of AMPK, reversed the effects of $\alpha$-LA and prevented protection from obesity.

In pancreatic islets of Langerhans, AMPK possesses a unique role, connecting cellular energy status to the capacity of beta cells to synthesise and secrete insulin. A number of studies have demonstrated that AMPK, when activated, transmits the signal of low glucose availability and leads to an inhibition of insulin secretion and expression [19-22]. While a role for AMPK in the beta cell continues to unfold, evidence for a role for $\alpha$-LA in islet function is lacking. Given that $\alpha$-LA modulates AMPK activity in the hypothalamus, and AMPK regulates insulin secretion, we investigated the possible role of $\alpha$-LA in beta cell function using isolated rat islets and the MIN6 beta cell line.

\section{Materials and methods}

Animals

Male C57/B16 mice, 2 to 3 months of age, were purchased from Charles River (Wilmington, MA, USA). All animals were handled according to the guidelines of the Canadian Council on Animal Care. All the protocols and procedures were approved by the Animal Care and Use Committee at the University of Toronto.

\section{Reagents}

$\alpha$-LA and metformin (1,1-dimethylbiguanide hydrochloride) were obtained from Sigma (Oakville, ON, Canada). AICAR was from Toronto Research Chemicals (North
York, ON, Canada). Rapamycin and all primary antibodies except anti-p70 s6 kinase (p70 s6k; Upstate, Lake Placid, NY, USA) were from Cell Signaling Technology (Beverly, MA, USA). Materials for rat insulin RIA were obtained from Linco Research (St Charles, MO, USA).

\section{Cell culture}

MIN6 insulinoma cells (passage 38-52), a gift from S. Seino (Chiba University, Chuo-ku, Japan), were cultured in Dulbecco's modified Eagle's medium with $25 \mathrm{mmol} / \mathrm{l}$ glucose, $10 \% \mathrm{FBS}, 100 \mathrm{U} / \mathrm{ml}$ penicillin $\mathrm{G}$ sodium, $100 \mu \mathrm{g} /$ $\mathrm{ml}$ streptomycin sulphate, and $\beta$-mercaptoethanol (1.7 $\mu \mathrm{l} / 500 \mathrm{ml})$ at $37^{\circ} \mathrm{C}$ and $5 \% \mathrm{CO}_{2}$. For overnight treatments, cells were cultured in growth medium with $\alpha$-LA, metformin or AICAR at the specified concentrations. For acute treatment for AMPK immunoblots, MIN6 cells were washed twice in KRBH buffer $(128.8 \mathrm{mmol} / \mathrm{l} \mathrm{NaCl}$, $4.8 \mathrm{mmol} / 1 \mathrm{KCl}, 1.2 \mathrm{mmol} / 1 \quad \mathrm{KH}_{2} \mathrm{PO}_{4}, 1.2 \mathrm{mmol} / \mathrm{l}$ $\mathrm{MgSO}_{4}, 2.5 \mathrm{mmol} / \mathrm{l} \mathrm{CaCl}, 5 \mathrm{mmol} / 1 \mathrm{NaH}_{2} \mathrm{CO}_{3}$, and $10 \mathrm{mmol} / 1 \mathrm{HEPES}$, pH 7.4 with $0.1 \% \mathrm{BSA}), 2.8$ or $15 \mathrm{mmol} / \mathrm{l}$ glucose, and then incubated in the same medium for $30 \mathrm{~min}$ or $1 \mathrm{~h}$. Cells were then washed twice before treatment with $\alpha$-LA.

\section{Islet isolations}

Islets of Langerhans were isolated from male Wistar rats by collagenase digestion and separated by density gradient centrifugation. Islets were maintained in RPMI containing $11.1 \mathrm{mmol} / \mathrm{l}$ glucose, $10 \mathrm{mmol} / \mathrm{l} \mathrm{HEPES}, 10 \% \mathrm{FBS}, 100 \mathrm{U} /$ $\mathrm{ml}$ penicillin $\mathrm{G}$ sodium and $100 \mu \mathrm{g} / \mathrm{ml}$ streptomycin sulphate and cultured at $37^{\circ} \mathrm{C}$ and $5 \% \mathrm{CO}_{2}$.

\section{Immunoblotting}

Samples were separated by SDS-PAGE on 8 to $12 \%$ polyacrylamide gels and transferred to PVDF-Plus membranes (BIORAD). Primary antibodies (see above) were detected with donkey anti-rabbit or anti-mouse (Amersham Biosciences, Baie d'Urfe, QC, Canada) at 1:7,500 for $1.5 \mathrm{~h}$ at room temperature. Visualisation was by chemiluminescence (ECL or ECL Plus; Amersham Biosciences) and exposure to Kodak film (Eastman Kodak, Rochester, NY, USA). Phospho-blots were normalised by stripping membranes and re-probing with polyclonal antibodies to AMPK, Akt or p70 s6k to control for loading. Band densities were quantified using Scion Image software (Scion Corporation, Frederick, MD, USA).

Insulin secretion

MIN6 cells were seeded in a 24-well plate at a density of $\sim 2 \times 10^{5}$ per well. Twenty-four hours later, cells were treated with the indicated reagents for overnight incuba- 
tion. Cells were then washed in glucose-free KRBH three times and pre-incubated twice for 30 min with the same medium. Following two more washes in KRBH, cells were incubated for $1 \mathrm{~h}$ in KRBH containing either 0 or $15 \mathrm{mmol} /$ 1 glucose as previously described [23]. Medium was saved and assayed for insulin content by RIA. For experiments involving acute treatment of MIN6 cells with $\alpha$-LA, AICAR or metformin, the respective compounds were added during the 1-h secretion period. All values were normalised to total DNA content.

Freshly isolated rat islets were cultured overnight and transferred to 6- or 12-well plates (20-25 islets per well) containing medium with the indicated treatments. Following overnight incubation, islets were washed in $\mathrm{KRBH}$ containing $2.8 \mathrm{mmol} / 1$ glucose, pre-incubated for $30 \mathrm{~min}$ in the same medium and then transferred to KRBH (2.8 $\mathrm{mmol} / \mathrm{l}$ glucose) for $90 \mathrm{~min}$, followed by $90 \mathrm{~min}$ in $\mathrm{KRBH}$ with $16.7 \mathrm{mmol} / \mathrm{l}$ glucose. Medium was collected for insulin RIA. For acute treatments, $\alpha$-LA was included during the 90-min secretion stages, and islets were used $24 \mathrm{~h}$ after isolation. Islets were lysed in $70 \%$ acid-ethanol solution for DNA quantification and subsequent normalisation.

\section{Perfusions}

Surgery and pancreatic perfusions were performed as described [24] on male C57/B16 mice, with minor modifications. KRBH medium was the same as for experiments in isolated islets and MIN6 cells except for the addition of 3\% dextran and a BSA concentration of $0.25 \%$. Samples were collected after a 20 -min pre-perfusion period.

\section{Cell growth}

Cell growth was assessed using the XTT cell proliferation assay (Proliferation Kit II; Roche Applied Sciences, Laval, QC, Canada) according to the manufacturer's instructions. Briefly, $2.5 \times 10^{4}$ cells per well were seeded into a 96-well tissue culture plate. Twenty-four hours after seeding, cells were treated with either $2.0 \mathrm{mmol} / \mathrm{l} \alpha$-LA or $5 \mathrm{nmol} / 1$ rapamycin and cultured for 24 to $72 \mathrm{~h}$, with daily refreshing of medium. Absorbance readings at $490 \mathrm{~nm}$ were recorded following the indicated treatment and $6 \mathrm{~h}$ of incubation with the XTT reagent.

\section{Microscopy}

MIN6 cells were seeded onto coverslips, and treated for $24 \mathrm{~h}$ with either $2.0 \mathrm{mmol} / 1 \alpha$-LA or $6 \mu \mathrm{mol} / 1$ staurosporine (Sigma). Cells were then incubated for $20 \mathrm{~min}$ with propidium iodide (Sigma) in medium containing (in mmol/l) $130 \mathrm{NaCl}, 5 \mathrm{KCl}, 5 \mathrm{NaHCO}_{3}, 2 \mathrm{CaCl}_{2}, 1 \mathrm{MgCl}_{2}$, 10 HEPES, $\mathrm{pH}$ 7.4. Coverslips were washed and transferred to an open chamber with the same medium. Fluorescent imaging was carried out using an Olympus
BX51W1 microscope fitted with a $20 \times / 0.95$ water immersion objective and cooled CCD camera at $36 \pm$ $1{ }^{\circ} \mathrm{C}$. For excitation, a xenon-lamp-based DeltaRam highspeed monochromator (Photon Technology International [PTI], London, ON, Canada) was used. Excitation and emission wavelengths were 540 and $660 \mathrm{~nm}$, respectively. ImageMaster 3 software (PTI) was used for monochromator and videocamera control, as well as for imaging and data collection.

Mitochondrial membrane potential $\left(\Delta \Psi_{\mathrm{m}}\right)$, oxygen consumption and reactive oxygen species (ROS) production

Measurements were performed as previously described [25], except that $\alpha$-LA was added to the cells prior to measurements. Oxygen consumption measurements were performed using a Clark-type electrode coupled to an Oxygraph unit (Hansatech, Pentney, UK). $\Delta \Psi_{\mathrm{m}}$ was monitored by observing safranin $\mathrm{O}$ fluorescence using a FluoroCount plate reader (Packard Instruments, Meriden, CT, USA) at excitation/emission wavelengths of $530 / 590 \mathrm{~nm}$. A decrease in fluorescence corresponded to an increase in $\Delta \Psi_{\mathrm{m}}$. ROS production was assayed as hydrogen peroxide-induced formation of dichlorofluorescein (DCF; Sigma) from the non-fluorescent reduced form, and monitored at excitation/emission wavelengths $485 / 530 \mathrm{~nm}$. DCF was obtained from the stable compound DCF diacetate by alkaline hydrolysis.

\section{Statistics}

Data are presented as means \pm SE. Significance between groups was determined using an unpaired two-tailed Student's $t$-test or one-way ANOVA when appropriate. Significance was established at $p<0.05$.

\section{Results}

\section{Activation of AMPK signalling}

Treatment of islets with $2.0 \mathrm{mmol} / \mathrm{l} \alpha$-LA (a concentration similar to that used in other in vitro studies $[8,9])$ for 15 min led to an increase in phosphorylation of the AMPK $\alpha$-subunit at $\operatorname{Thr} 172(2.54 \pm 0.14$ fold $)$ compared with untreated islets $(p<0.001)$ (Fig. 1a,b). MIN6 cells treated with $\alpha$-LA $(0.5-2.0 \mathrm{mmol} / \mathrm{l})$ for $30 \mathrm{~min}$ also exhibited an increase in AMPK $\alpha$-subunit phosphorylation (Fig. 1c,d), a trend that occurred in a dose-dependent manner. The effect of $\alpha$-LA on downstream signalling of AMPK was also detected, demonstrating that AMPK activity was increased. AMPK phosphorylates acetyl CoA carboxylase (ACC) at Ser79 leading to an inhibition of fatty acid synthesis and an increase in the rate of $\beta$-oxidation [15]. $\alpha$-LA treatment of islets and MIN6 cells caused phosphorylation of ACC, a trend that increased dose-dependently in MIN6 cells 
(Fig. 1). Figure 1e shows that AMPK is inhibited by glucose, and that $\alpha$-LA activated AMPK at both low $(2.8 \mathrm{mmol} / \mathrm{l})$ and high $(15 \mathrm{mmol} / \mathrm{l})$ glucose concentrations.

We also investigated if $\alpha$-LA caused a sustained increase in AMPK activity. AMPK phosphorylation in rat islets treated for $18 \mathrm{~h}$ with $\alpha$-LA was increased by $1.58 \pm 0.24$ fold compared with controls (Fig. 2a,b). MIN6 cells treated for $18 \mathrm{~h}$ with $\alpha$-LA $(0.5-2.0 \mathrm{mmol} / \mathrm{l})$ also showed a sustained phosphorylation of AMPK (Fig. 2c,d). ACC phosphorylation was also detected in both MIN6 cells and islets following overnight treatment with $\alpha$-LA.

a

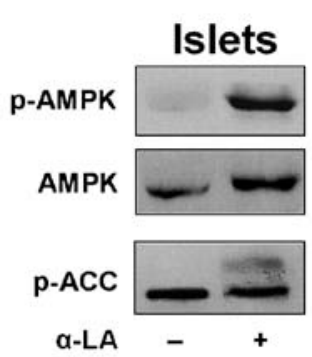

b

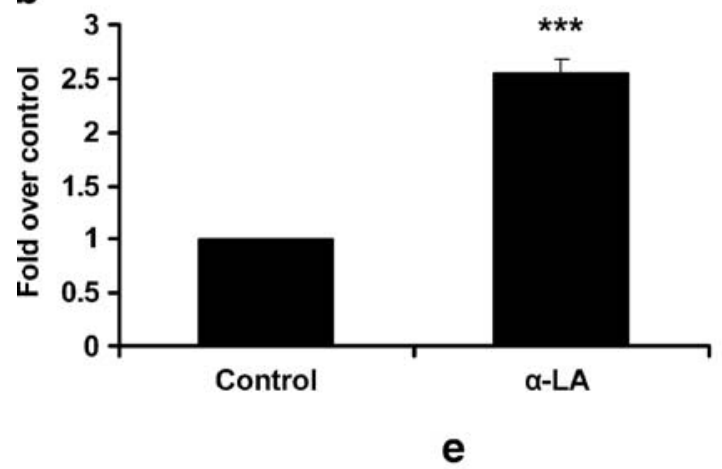

Inhibition of insulin secretion

Activation of AMPK in beta cells using AICAR or metformin results in a reduced capacity for insulin secretion [21, 26, 27]. To investigate if $\alpha$-LA would elicit similar effects, isolated rat islets were cultured for $18 \mathrm{~h}$ in $2.0 \mathrm{mmol} / 1 \alpha$-LA or $1.0 \mathrm{mmol} / 1 \mathrm{AICAR}$. The AMP analogue AICAR allosterically binds AMPK, making it a better target for phosphorylation and activation by an upstream kinase [28]. We observed an inhibition of glucose-stimulated insulin secretion (GSIS) at $16.7 \mathrm{mmol} / 1$ glucose by $\alpha$-LA $(63 \pm 5.8 \%$ of controls, $p<0.01)$ and AICAR $(64 \pm 6.9 \%$ of controls, $p<0.05)$ (Fig. 3a). When the experiments were repeated with metformin $(1.0 \mathrm{mmol} / \mathrm{l})$, another AMPK-activating compound, we found that following an 18-h treatment, insulin

C

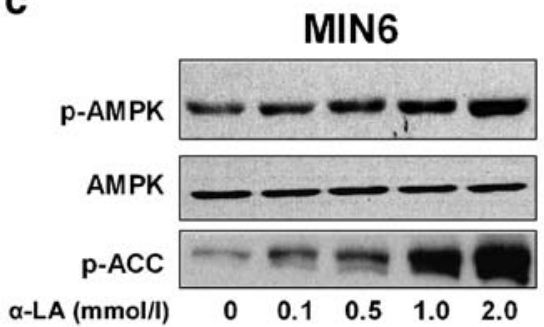

d

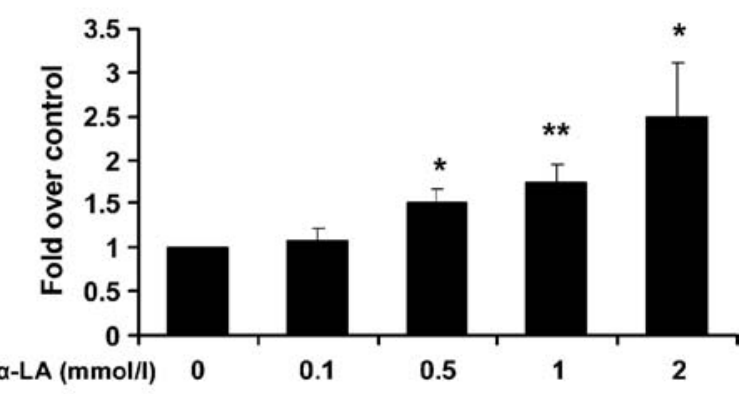

\section{MIN6}

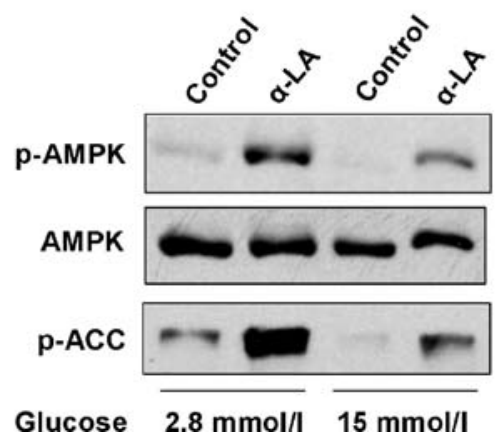

Fig. $1 \alpha$-LA acutely induces AMPK phosphorylation in rat islets and MIN6 cells. a Isolated rat islets were incubated in $\mathrm{KRBH}$ containing $2.8 \mathrm{mmol} / 1$ glucose for $1 \mathrm{~h}$ and then $16.7 \mathrm{mmol} / 1$ glucose with or without $2.0 \mathrm{mmol} / 1 \alpha$-LA for $15 \mathrm{~min}$. Representative immunoblots for phospho (p)- and total AMPK and phospho-ACC. b Relative changes in AMPK phosphorylation, represented as band density for phospho-AMPK normalised to total AMPK $(n=3)$. c MIN6 cells were cultured for $30 \mathrm{~min}$ in KRBH containing the indicated concentrations of $\alpha$-LA and glucose $(15 \mathrm{mmol} / \mathrm{l})$. Representative blots for phospho- and total AMPK and phosphoACC. d Relative changes in AMPK phosphorylation $(n=4)$. e MIN6 cells were treated for $1 \mathrm{~h}$ in KRBH containing 2.8 or $15 \mathrm{mmol} / 1$ glucose in the presence or absence of $2 \mathrm{mmol} / \mathrm{l} \alpha$-LA. Immunoblots for phospho- and total AMPK and phospho-ACC. Results are shown as means \pm SE. ${ }^{*} p<0.05 ; * * p<0.01 ; * * * p<0.001$ 
Fig. 2 Effect of chronic (18 h) $\alpha$-LA treatment on AMPK in MIN6 cells and rat islets.

a Isolated rat islets were cultured overnight in $2.0 \mathrm{mmol} / 1$ $\alpha$-LA. Representative immunoblots are for phospho (p)- and total AMPK and phospho-ACC. b Band densities for phosphoand total AMPK $(n=9)$. c MIN6 cells were cultured overnight in the indicated concentrations of $\alpha$-LA. Representative immunoblots are for phospho- and total AMPK and phospho-ACC. d Relative changes in AMPK phosphorylation analysed by densitometry. Results are shown as means \pm SE, $(n=3)$. ${ }^{*} p<0.05$; $* * p<0.01 ; * * * p<0.001$ a
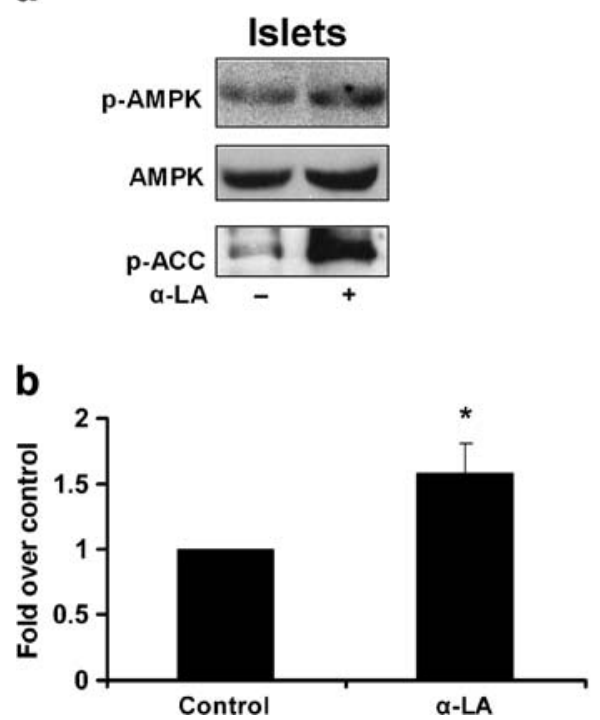

C
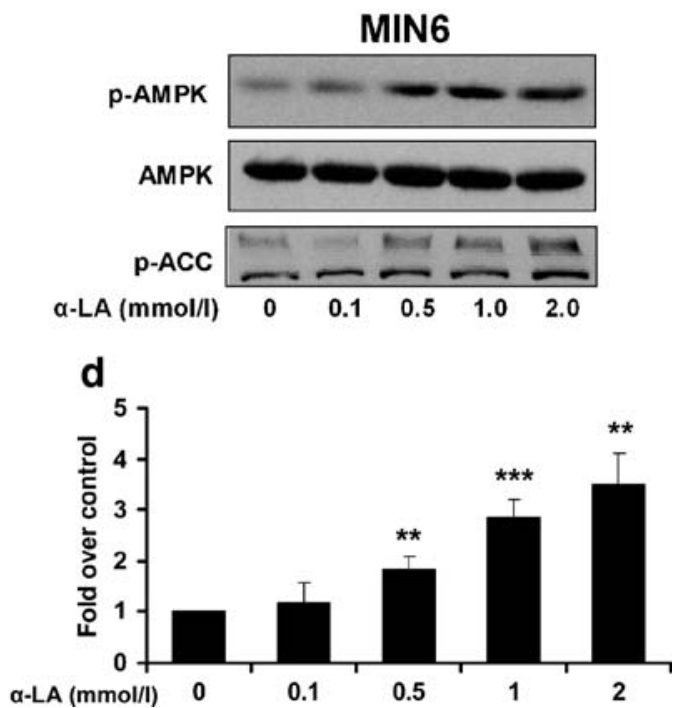

secretion under high glucose $(16.7 \mathrm{mmol} / \mathrm{l})$ was $25 \pm 7.3 \%$ less than untreated control islets ( $p<0.05$, data not shown).

Similar observations were made with MIN6 cells treated chronically with $\alpha$-LA, AICAR or metformin. Compared with controls, $\alpha$-LA $(2.0 \mathrm{mmol} / \mathrm{l})$ attenuated insulin secretion at $15 \mathrm{mmol} / \mathrm{l}$ glucose by $30 \pm 5.3 \% \quad(p<0.01)$ (Fig. 3b). AICAR (1.0 mmol/l) and metformin (1.0 mmol/l) also reduced GSIS, by $55 \pm 4.2 \%(p<0.001)$ and $50 \pm 3.7 \%$ $(p<0.001)$, respectively. At low glucose, $\alpha$-LA inhibited secretion by $25 \pm 7.3 \%(p<0.05)$. As shown in Fig. 3c, immunoblots confirmed that AMPK activation was achieved with all three drugs. Total insulin content in MIN6 cells was significantly decreased in cells treated overnight with $\alpha$-LA and AICAR ( $70 \%$ of controls, $p<0.001$ for both conditions, Fig. $3 \mathrm{~d}$ ). In order to rule out non-specific effects of $\alpha$-LA due to cytotoxicity, we a

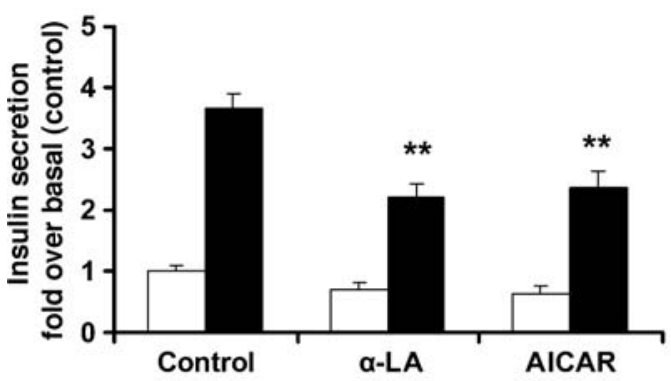

C

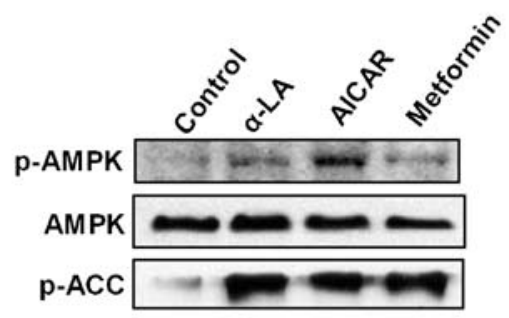

b

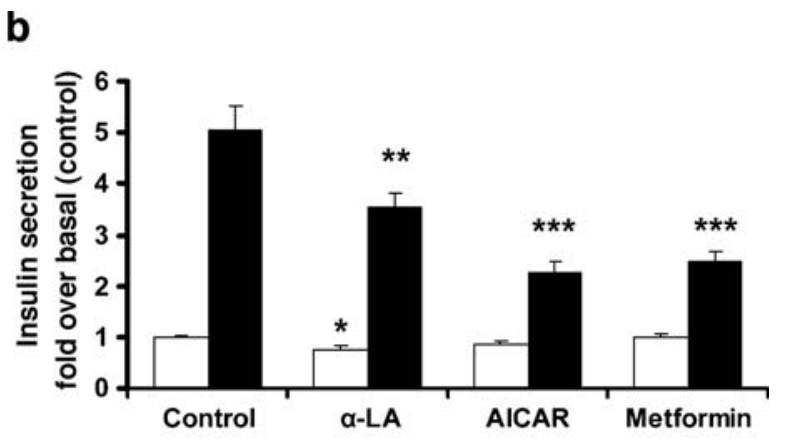

d

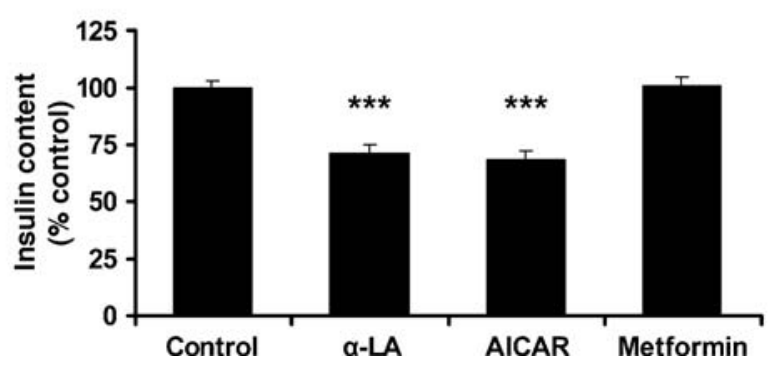

glucose $(n=3-4)$. c Representative blots for phospho (p)-AMPK, total AMPK and phospho-ACC in MIN6 cells are shown for each condition following $18 \mathrm{~h}$ treatment as in (b). d Total insulin content was measured from MIN6 cells cultured overnight in $2.0 \mathrm{mmol} / 1 \alpha$ LA, $1.0 \mathrm{mmol} / 1$ AICAR or $1.0 \mathrm{mmol} / 1$ metformin $(n=3-4)$. All values were normalised to total DNA. $* p<0.05 ; * * p<0.01$; $* * * p<0.001$ compared with control values. Results are given as means $\pm \mathrm{SE}$
Fig. 3 Inhibition of insulin secretion by $\alpha$-LA. a Isolated rat islets were cultured for $18 \mathrm{~h}$ in medium containing $2.0 \mathrm{mmol} / \mathrm{l} \alpha$-LA or $1.0 \mathrm{mmol} / 1 \mathrm{AICAR}$ and assayed for insulin secretion. Secretion was measured following $90 \mathrm{~min}$ incubation at 2.8 (open bars) or $16.7 \mathrm{mmol} / 1$ (closed bars) glucose $(n=4)$. b MIN6 cells were cultured overnight in $2.0 \mathrm{mmol} / 1 \alpha$-LA, $1.0 \mathrm{mmol} / 1$ AICAR or $1.0 \mathrm{mmol} / 1 \mathrm{metformin}$. Insulin secretion was measured following $1 \mathrm{~h}$ in $\mathrm{KRBH}$ containing either 0 (open bars) or $15 \mathrm{mmol} / 1$ (closed bars) 
a
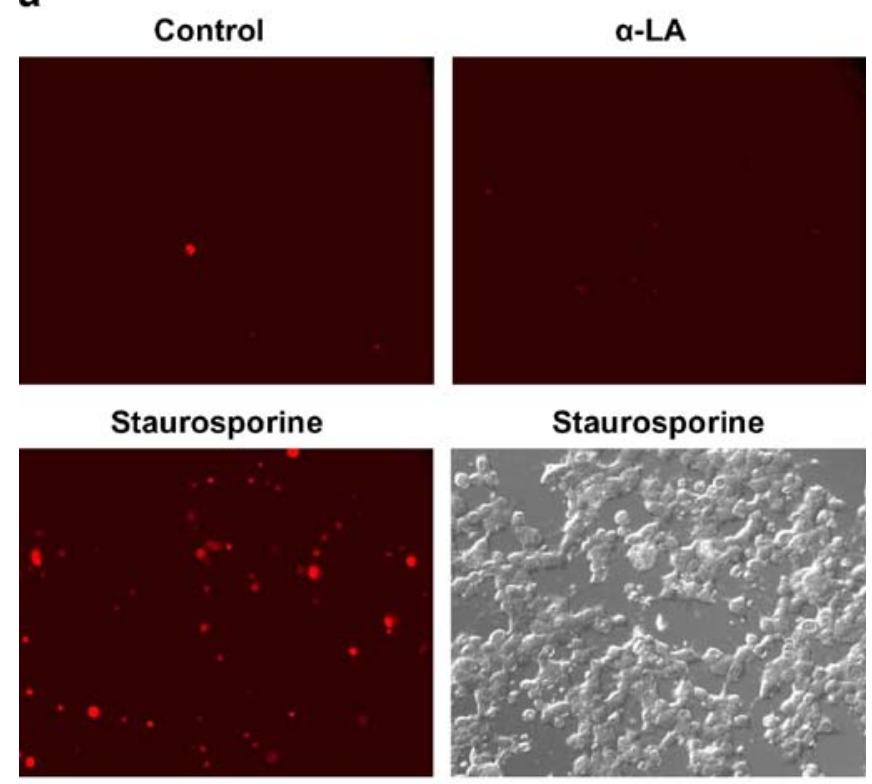

Staurosporine

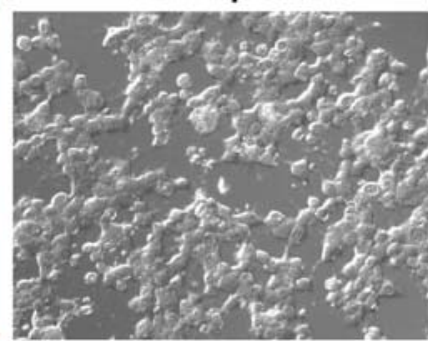

b

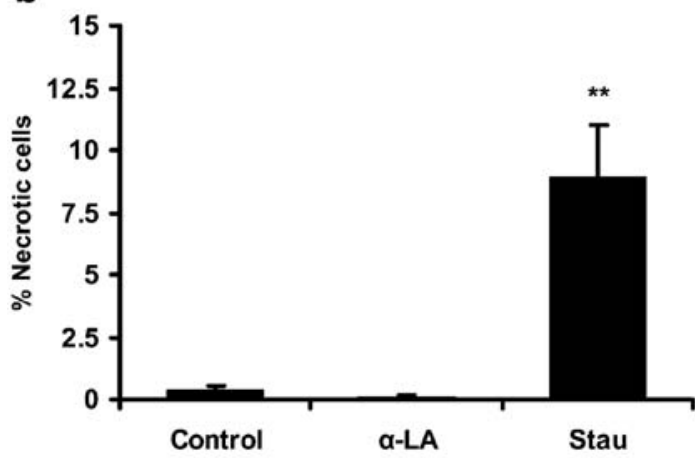

Fig. 4 Effect of $\alpha$-LA on cell viability. Representative images (a) of MIN6 cells stained with propidium iodide following a 24-h treatment with control medium, $2.0 \mathrm{mmol} / 1 \alpha$-LA or $6 \mu \mathrm{mol} / 1$ staurosporine $(\mathrm{Stau})$. Light microscopy is also shown for staurosporine-treated cells. b The percentage of necrotic cells treated under the above conditions, with results given as the means $\pm \mathrm{SE}$ $(n=3) .{ }^{* *} p<0.01$

measured the effect of this compound on necrosis. Cell death in MIN6 cells treated with $2.0 \mathrm{mmol} / \mathrm{l} \alpha$-LA for $24 \mathrm{~h}$ was not different from controls, whereas staurosporine, an inducer of cell death [29], caused marked necrosis (Fig. 4).

\section{Acute inhibition of insulin secretion}

In addition to inhibiting secretion after overnight exposure, we found that $\alpha$-LA also had acute inhibitory effects. When rat islets were challenged with glucose in the presence of $\alpha$-LA, we observed a $45 \pm 3 \% \quad(p<0.01)$ inhibition of GSIS compared with controls (Fig. 5a). Also, $\alpha$-LA acutely activated AMPK, and inhibited GSIS from MIN6 cells at both $0 \mathrm{mmol} / 1(29 \pm 5.1 \%, p<0.01)$ and $15 \mathrm{mmol} / \mathrm{l}$ glucose $(28 \pm 5.2 \%, p<0.05)$ compared with controls. Interestingly, despite inducing phosphorylation of
AMPK, AICAR and metformin did not affect GSIS (Fig. 5b,c). Subsequent experiments in isolated rat islets acutely treated with AICAR and metformin also showed no significant effect (not shown). In addition to its effects on isolated islets and MIN6 cells during a static glucose challenge, $\alpha$-LA $(0.5 \mathrm{mmol} / \mathrm{l})$ dramatically reduced GSIS in the perfused mouse pancreas (Fig. 5d). This effect was primarily evident in the first phase of insulin secretion (during the first 6-12 min).

Mammalian target of rapamycin (mTOR)/p70 s6k signalling and cell growth

Signalling by mTOR controls translation and cell growth (reviewed in [30]), and is inhibited by AMPK [31]. We found that $\alpha$-LA reduced phosphorylation of the mTOR target $\mathrm{p} 70 \mathrm{~s} 6 \mathrm{k}$ at $\mathrm{Thr} 389$ by $63 \pm 7 \%$ (Fig. 6a,b). AICAR and metformin also inhibited p70 s6k, by $50 \pm 5$ and $46 \pm 13 \%$, respectively (Fig. 6a,b). As well, MIN6 cells treated for $24 \mathrm{~h}$ with $\alpha$-LA $(2 \mathrm{mmol} / \mathrm{l})$, AICAR $(1 \mathrm{mmol} / \mathrm{l})$ or rapamycin $(5 \mathrm{nmol} / \mathrm{l})$, an inhibitor of mTOR, also had markedly reduced phosphorylation of p70 s6k (Fig. 6c). We also observed a decrease in the phosphorylation of the s6 ribosomal subunit (Ser235/236) and eukaryotic initiation factor 4E-binding protein 1 at Ser65 (Fig. 6d), two phosphorylation targets of $\mathrm{mTOR} / \mathrm{p} 70$ s6k signalling [32, 33]. The phospho-state of Akt (Thr308) and eukaryotic initiation factor 4E (Ser209), other molecules involved in translational control, remained unchanged (Fig. 6d). As well, we found that cell growth was decreased similarly in MIN6 cells treated for 24-72 h with $\alpha$-LA (Fig. 6e) or rapamycin (Fig. 6f), compared with controls, as indicated by an XTT cell proliferation assay.

\section{Effect of rapamycin on insulin secretion}

In order to determine if the decrease in insulin secretion and insulin content we observed with $\alpha$-LA was due to an inhibition of mTOR, we investigated the effect of rapamycin on these parameters. Interestingly, MIN6 cells treated with $5 \mathrm{nmol} / \mathrm{l}$ rapamycin for $24 \mathrm{~h}$ actually secreted more insulin than untreated controls $(129 \pm 13 \%$ at low glucose, $136 \pm 13 \%$ at high glucose, both $p<0.05)$, possibly in part due to an increase in insulin content $(121 \pm 8 \%$ compared with controls, $p<0.01$ ), as shown in Fig. $6 \mathrm{~g}$, h. These data suggest that while mTOR may mediate the effect of $\alpha$-LA on cell growth, it is unlikely that it regulates the reduction in GSIS and total insulin content.

\section{$\Delta \Psi_{\mathrm{m}}$ and ROS production}

The acute inhibitory effect of $\alpha$-LA on insulin secretion appeared to have an AMPK-independent component. Given the reported ability of $\alpha$-LA to induce a mitochondrial uncoupling effect [34], and that the primary regulator of insulin secretion, cytosolic ATP:ADP ratio, is main- 
a

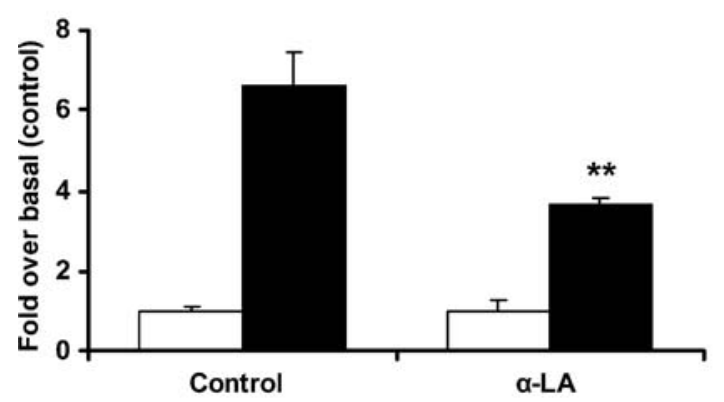

C

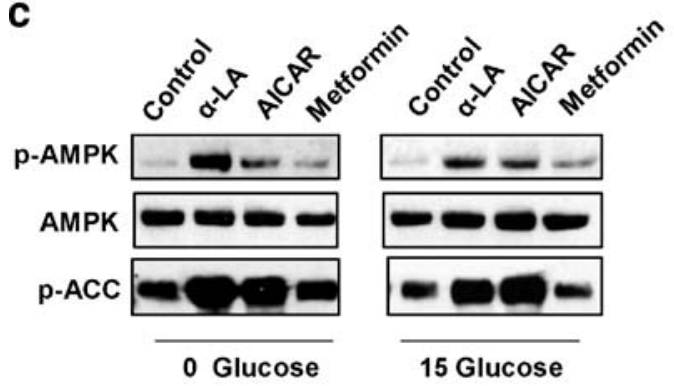

b

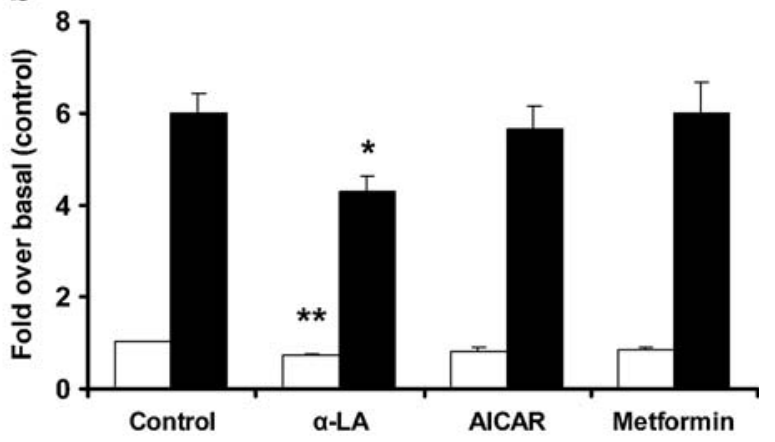

d

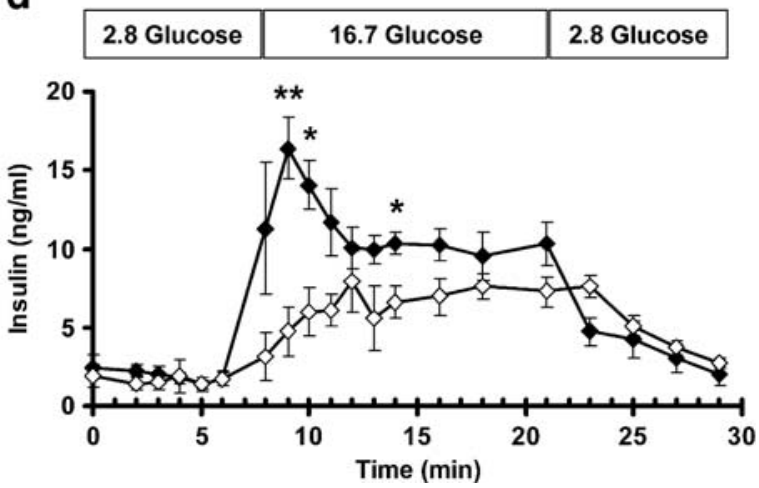

phospho (p)- and total AMPK and phospho-ACC are shown for each condition in (b). d Mouse pancreata were perfused with (open symbols) or without (closed symbols, control) KRBH containing $0.5 \mathrm{mmol} / \mathrm{l} \alpha$-LA. Glucose concentrations are shown in $\mathrm{mmol} / \mathrm{l}$. Samples were collected after a pre-perfusion period of $20 \mathrm{~min}$ at $2.8 \mathrm{mmol} / 1$ glucose. Data are given as means $\pm \mathrm{SE}$ from four separate animals under each condition. ${ }^{*} p<0.05 ;{ }^{*} p<0.01$ compared with untreated controls

mitochondrial ROS production in the presence of $\alpha$-LA $(200 \mu \mathrm{mol} / \mathrm{l})$. Thus, our data suggest that $\alpha$-LA can elevate the mitochondrial level of ROS and probability of MPT opening.

\section{Discussion}

In this report, we have demonstrated several novel properties of $\alpha$-LA, including the activation of AMPK in rat islets and MIN6 cells. The role of $\alpha$-LA as a regulator of AMPK has only recently been demonstrated. Whereas Kim et al. [18] showed that this compound inhibited hypothalamic AMPK activity, we have shown the opposite to be true in beta cells. Our observation of AMPK activation by $\alpha$-LA in pancreatic beta cells suggests that AMPK is responsible for some of the reported effects found with $\alpha$ LA in other tissues. For example, $\alpha$-LA facilitates glucose uptake in both skeletal muscle and adipose tissue in vitro $[8,9]$. Indeed, others have demonstrated that AMPK activation in these tissues leads to improved insulin sensitivity and enhanced glucose uptake and utilisation $[13,15-17]$. Furthermore, both AMPK activation [14, 17] and $\alpha$-LA [10] are associated with suppression of hepatic glucose output. Very recently, two reports described that production in the respiratory chain, demonstrated increased behave as both a pro-oxidant [34] and inducer of MPT [37] we tested the effect of $\alpha$-LA on mitochondrial ROS production. Indeed, kinetics of respiration-dependent DCF oxidation (Fig. 7c,e), which reflects oxygen radical
Fig. 5 Acute inhibition of insulin secretion by $\alpha$-LA. a Rat islets
were cultured for $90 \mathrm{~min}$ in KRBH with $2.8 \mathrm{mmol} / 1$ (open bars) or $16.7 \mathrm{mmol} / 1$ (closed bars) glucose in the absence/presence of bars) or $15 \mathrm{mmol} / 1$ (closed bars) glucose in the presence of
(c) $2.0 \mathrm{mmol} / 1 \alpha$-LA, $1.0 \mathrm{mmol} / 1 \mathrm{AICAR}$ or $1.0 \mathrm{mmol} / 1 \mathrm{metformin}$ fo $1 \mathrm{~h}$ and assayed for insulin secretion at 0 or $15 \mathrm{mmol} / 1$ glucose opening of non-specific pores in the mitochondrial inner membrane and is induced by $\mathrm{Ca}^{2+}$ in the presence of riety of co-inducers, such as inorganic phosphate, thio oxidants and fatty acids (reviewed in [36]). Next, we considered how $\alpha$-LA might influence MPT opening. Since MPT can be induced by ROS [36], and $\alpha$-LA can

tained by mitochondrial oxidative phosphorylation [35], function in permeabilised MIN6 cells. Oxidative phosphorylation was not affected by $\alpha$-LA $(200 \mu \mathrm{mol} / \mathrm{l})$, but mitochondrial function, was clearly dependent on $\alpha$-LA. Incremental addition of $\mathrm{Ca}^{2+}$ to respiring mitochondria causes acceleration of oxygen consumption and membrane of which were more pronounced in the presence of $\alpha$-LA (Fig. 7a,b,d). Both parameters could be reverted to initial levels with cyclosporin $\mathrm{A}$, a classic inhibitor of $\mathrm{Ca}^{2+}$ induced mitochondrial permeabilisation (so-called mitochondrial permeability transition [MPT] [36]). MPT is an 

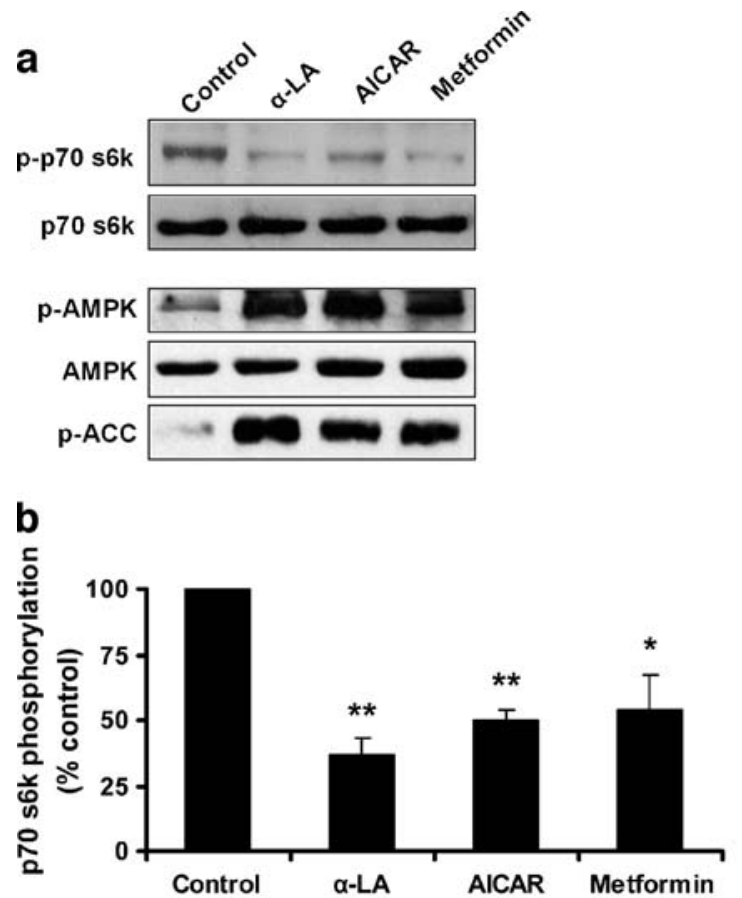

C

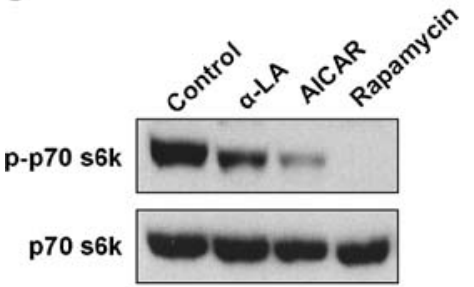

d

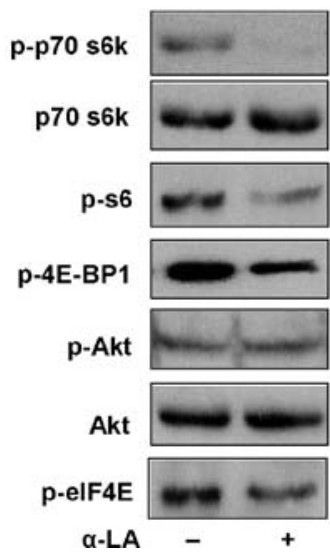

Fig. $6 \alpha$-LA negatively regulates $m T O R / p 70$ s6k signalling. a MIN6 cells were serum-starved in $5 \mathrm{mmol} / 1$ glucose for $4-5 \mathrm{~h}$ and treated for $30 \mathrm{~min}$ with $10 \%$ serum and $25 \mathrm{mmol} / 1$ glucose in the presence or absence of $2.0 \mathrm{mmol} / 1 \alpha$-LA, $2.0 \mathrm{mmol} / 1 \mathrm{AICAR}$ or $2.0 \mathrm{mmol} / \mathrm{l}$ metformin. Representative immunoblots are for phospho (p)- and total p70 s6k, as well as the AMPK/ACC pathway. b Relative changes in $\mathrm{p} 70 \mathrm{~s} 6 \mathrm{k}$ phosphorylation under the conditions in (a), represented as band density. Results are means $\pm \operatorname{SE}(n=3)$. c MIN6 cells were treated for $24 \mathrm{~h}$ with $2 \mathrm{mmol} / 1 \alpha$-LA, $1 \mathrm{mmol} / 1$ AICAR or $5 \mathrm{nmol} / \mathrm{l}$ rapamycin. Blots are shown for phospho- and total p70 s6k. d MIN6 cells were treated for $30 \mathrm{~min}$ with $2.0 \mathrm{mmol} / 1$ $\alpha$-LA in $25 \mathrm{mmol} / 1$ glucose and $10 \%$ serum. Representative e

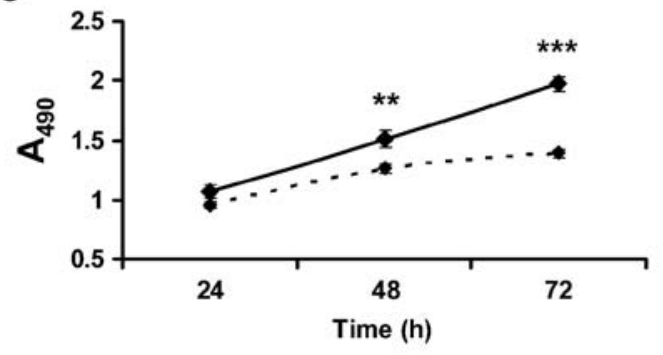

$\mathbf{f}$

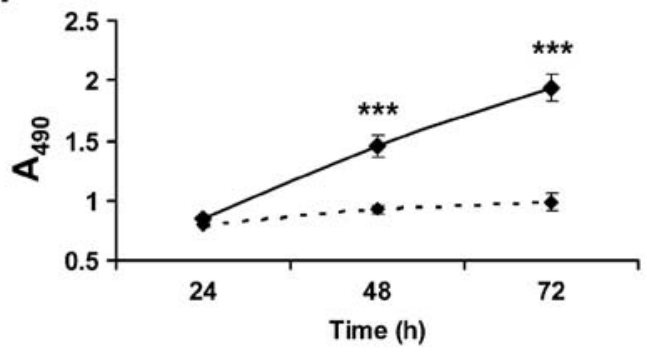

g

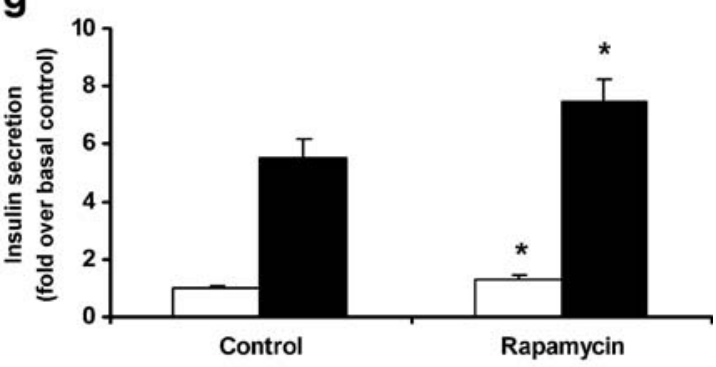

h

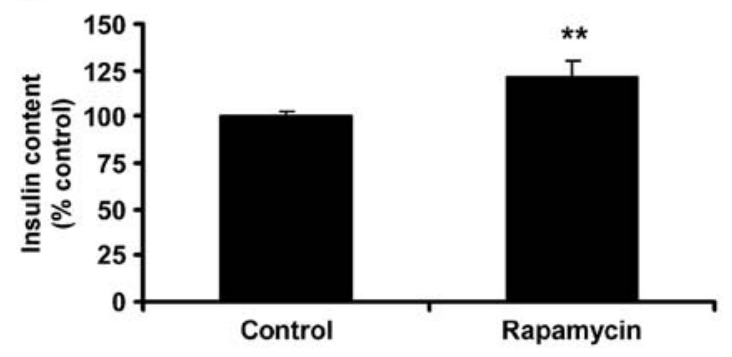

blots are for the indicated proteins ( $n=3$ independent experiments). e, f MIN6 cells were cultured in the presence (dashed line) or absence (unbroken line) of $2.0 \mathrm{mmol} / 1 \alpha$-LA (e) or in the presence (dashed line) or absence (unbroken line) of $5 \mathrm{nmol} / \mathrm{l}$ rapamycin (f) for 24-72 $\mathrm{h}$ and cell growth was measured using an XTT assay $(n=3)$. $\mathbf{g}, \mathbf{h}$ Effect of rapamycin on insulin secretion from MIN6 cells. g Insulin secretion at 0 (open bars) or $15 \mathrm{mmol} / 1$ (closed bars) glucose from MIN6 cells treated for $24 \mathrm{~h}$ with $5 \mathrm{nmol} / 1$ rapamycin $(n=3)$. h Total insulin content in MIN6 cells treated for $24 \mathrm{~h}$ with $5 \mathrm{nmol} / 1$ rapamycin $(n=4)$. All secretion and total insulin data were normalised to total DNA and are expressed as means \pm SE. ${ }^{*} p<0.05$; ${ }^{* *} p<0.01 ; * * * p<0.001$ compared with controls 
a

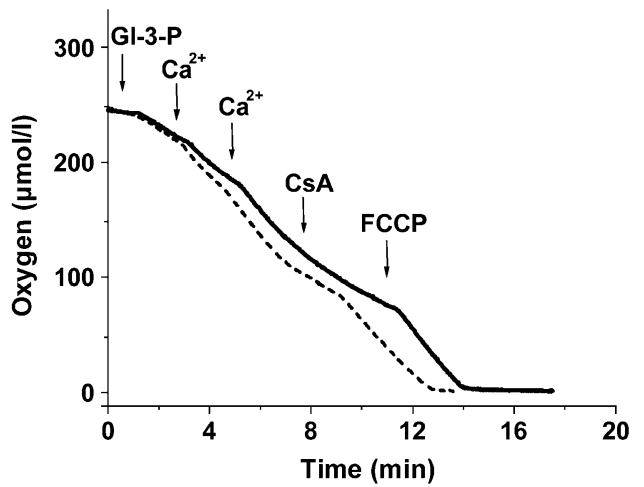

C

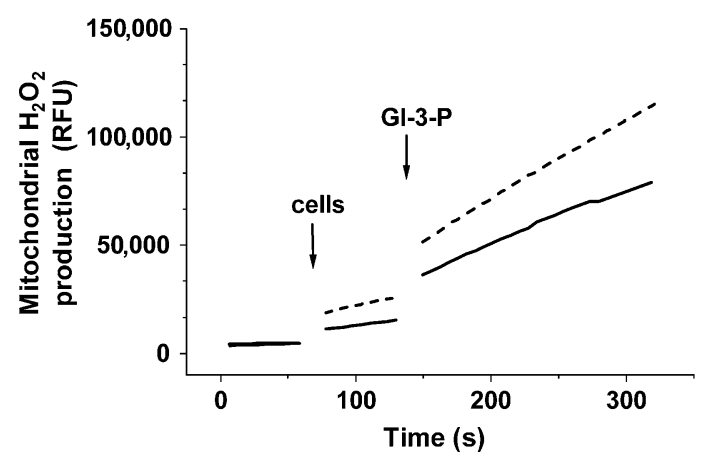

Fig. 7 Effect of $\alpha$-LA on mitochondrial parameters in permeabilised MIN6 cells. MPT opening monitored by $\mathrm{Ca}^{2+}$-induced oxygen consumption (a) and mitochondrial depolarisation (b) in the presence (broken line) or absence (unbroken line) of $200 \mu \mathrm{mol} / 1$ $\alpha$-LA. For (b), increasing fluorescence corresponds to reduced $\Delta \Psi_{\mathrm{m}}$. Representative traces are shown for each. c Sample traces of ROS measurements from cells treated with (broken line) or without (unbroken line) $200 \mu \mathrm{mol} / 1 \quad \alpha$-LA. Arrows $(\mathbf{a}-\mathbf{c})$ indicate the timepoints for addition of respiratory substrate glycerol-3-phosphate $(G l-3-P, 8 \mathrm{mmol} / \mathrm{l})$, MPT inducer $\mathrm{Ca}^{2+}(50 \mu \mathrm{mol} / \mathrm{l})$, MPT inhibitor

$\alpha$-LA acted as an insulin sensitiser in skeletal muscle [38], and prevented endothelial cell dysfunction in obese rats [39], effects shown to be attributable to AMPK activation. Thus, it is likely that AMPK is responsible for many of the diverse antidiabetic effects of this compound.

The beneficial properties of $\alpha$-LA, in particular as an antioxidant $[1,3,4]$ and stimulator of glucose uptake, make this a potentially useful agent for diabetes therapy. However, we have shown here that $\alpha$-LA inhibits insulin secretion in vitro from MIN6 cells and isolated rat islets. These findings are supported by other reports describing similar inhibitory effects with metformin or AICAR [21, $26,27]$. It is likely that the negative regulation of insulin secretion and positive effect on insulin sensitivity by these three drugs are mediated by AMPK. Several studies have shown that AMPK suppresses insulin secretion and synthesis in beta cells [19, 21, 22], consistent with its role as an energy-conserving enzyme. There are a number of possible mechanisms by which $\alpha$-LA may inhibit insulin secretion through AMPK. This enzyme has been shown to have an important role in suppressing preproinsulin promoter activity [21]. It has also been demonstrated that b

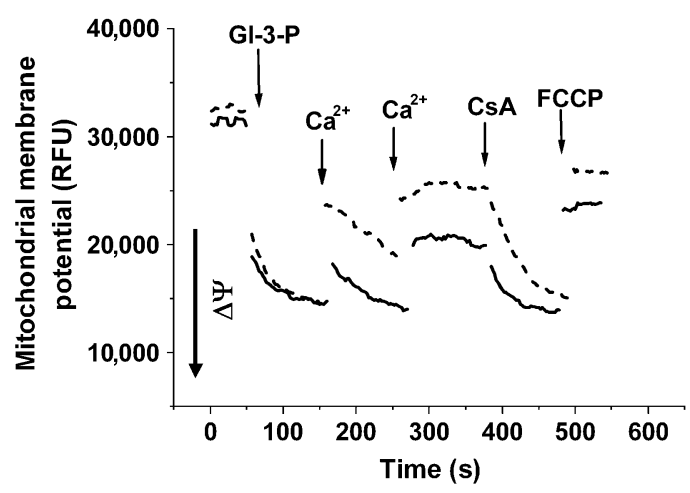

d

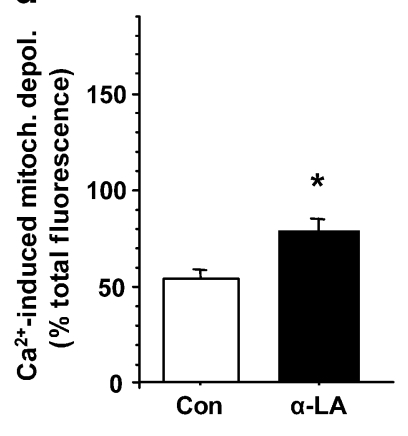

e

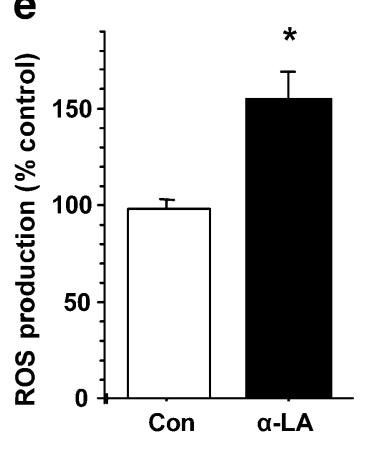

cyclosporin A $(C s A, 1 \mu \mathrm{mol} / \mathrm{l})$ and mitochondrial uncoupler $p$ trifluoromethoxy carbonyl cyanide phenyl hydrazone (FCCP, $1 \mu \mathrm{mol} / 1)$. RFU relative fluorescence units. All experiments were conducted at least three times with similar results. d Statistical data (from $\mathbf{b}$ and $\mathbf{c}$ ) for mitochondrial depolarisation (mitoch depol) induced by $100 \mu \mathrm{mol} / 1 \mathrm{Ca}^{2+}$ expressed as a percent of total fluorescent signal, and (e) for rate of respiration-dependent ROS production expressed as a percent of control value. ${ }^{*} p<0.05$ compared with control (Con)

activation of AMPK leads to modulation of secretory vesicle dynamics [22]. More recently, Richards et al. [40] showed that mouse islets infected with a constitutively active AMPK $\alpha$-subunit had reduced glucose oxidation and insulin secretion, and were associated with poorer glycaemic control when transplanted into streptozotocindiabetic mice compared with islets infected with null or dominant-negative AMPK viruses.

AMPK is an important regulator of the cellular response to nutrient availability, including protein translation and cell growth, and when activated, AMPK inhibits mTOR/ p70 s6k signalling [31]. However, whether mTOR is involved in AMPK-mediated inhibition of insulin secretion is currently not known. Consistent with a positive role for p70 s6k in insulin secretion, mice lacking this enzyme have impaired GSIS and reduced beta cell mass [41]. We have shown in this report that $\alpha$-LA inhibits $\mathrm{mTOR} / \mathrm{p} 70 \mathrm{~s} 6 \mathrm{k}$ signalling and cell growth in MIN6 cells, and reduces GSIS and insulin content. While rapamycin and $\alpha$-LA both caused inhibitory effects on cell growth and p70 s6k phosphorylation, the effect we observed with rapamycin on GSIS - a stimulatory one - is not consistent with a positive 
role for mTOR in insulin secretion. In agreement with our data, one report demonstrated that rapamycin improved insulin secretion in vivo in dogs following islet autografts [42]. While others have shown that rapamycin has inhibitory effects in rat islets, these observations were made only at high doses and treatment times of greater than 3 days [43]. Another report demonstrated that rapamycin treatment $(48 \mathrm{~h})$ was detrimental to GSIS from HIT-T15 cells, but not rat islets treated for $24 \mathrm{~h}$ [44]. These discrepancies may be due to differential sensitivity to rapamycin in assorted cell lines or animal species, or variations in experimental protocols. The fact that $\mathrm{p} 70 \mathrm{~s} 6 \mathrm{k}$ knock-out mice have reduced GSIS [41] may be a reflection of a total-body loss of this enzyme and thus is likely to include contributions from the effects of p70 s6k deficiency in other tissues, including enhanced insulin sensitivity in the periphery [45]. More studies are required in order to clearly understand if rapamycin and/or mTOR exhibit any significant effect on insulin secretion, and if AMPK is involved in this process.

We demonstrated here that in addition to prolonged exposure to $\alpha$-LA, acute treatment also inhibited insulin secretion from isolated rat islets, MIN6 cells and the perfused mouse pancreas. Previous reports [19, 21] suggested that acute AMPK activation inhibits GSIS. Although we cannot completely rule out this possibility, our data suggest that acute activation of AMPK was not exclusively responsible for our observations, given that AMPK and ACC phosphorylation were induced by AICAR, and to a lesser extent, metformin, yet these drugs did not have an acute inhibitory effect on insulin secretion (Fig. 5b,c). It is possible that potential nonspecific effects of AICAR, or differences in cell lines or experimental protocols, could account for the differences observed here compared with those of the Hardie [19] and Rutter [21] laboratories. Our data indicate that $\alpha$-LA may acutely inhibit insulin secretion via an alternative route involving direct actions on beta cell mitochondria-a process consisting of increased ROS production and induction of MPT opening. This would partially depolarise the mitochondria, thereby reducing the proton-motive force and thus ATP synthesis and, consequently, insulin secretion. Observations of increased ROS in isolated rat soleus muscle treated with $\alpha$-LA [34], and ROS-induced MPT in rat liver mitochondria by $\alpha$-LA [37], support our data that this compound can possess pro-oxidant properties. Our findings are important, given the clinical relevance of $\alpha$ LA as an antioxidant [5]. It is possible that at particular concentrations, or in the absence of other pro-oxidants, $\alpha$ LA itself acts as a pro-oxidant, whereas under conditions of oxidative stress, such as diabetes [5], this compound exhibits beneficial protective properties. As such, the clinical usefulness of $\alpha$-LA may be contingent upon a particular pathophysiological state. It is not known if $\alpha$ LA-induced ROS generation or mitochondrial depolarisation serves as a stimulus for AMPK activation by an upstream kinase such as LKB1 [12] or $\mathrm{Ca}^{2+}$ /calmodulindependent protein kinase kinase [46], but this remains an interesting possibility. Figure 8 depicts a potential scheme

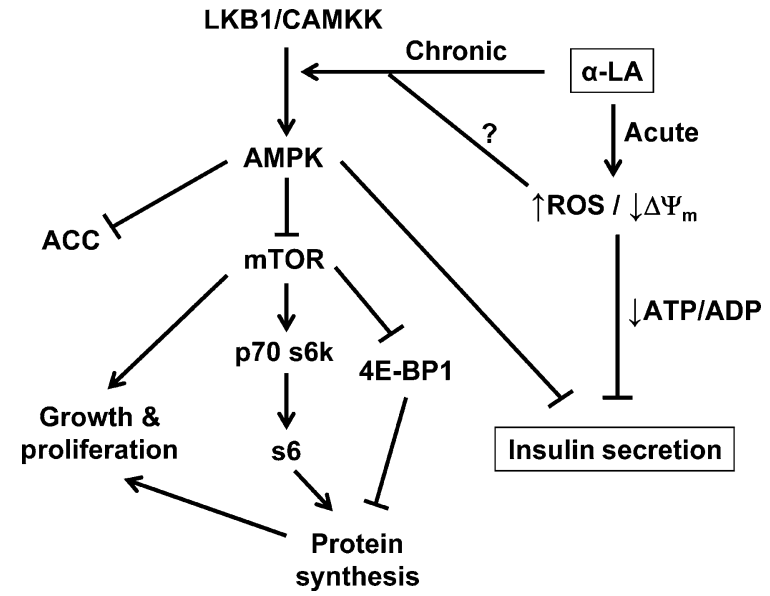

Fig. 8 Model of $\alpha$-LA regulation of AMPK and beta cell function. Acutely, $\alpha$-LA may inhibit GSIS by stimulating ROS and reducing $\Delta \Psi_{\mathrm{m}}$, thus impairing the cellular response to glucose stimulation. These effects may also serve as a stimulus for AMPK activation by an upstream kinase such as LKB1 serine/threonine kinase $(L K B 1)$ or $\mathrm{Ca}^{2+} /$ calmodulin-dependent protein kinase kinase (CAMKK) AMPK activation subsequently inhibits insulin secretion and cell growth. Arrows represent activation or stimulation; blunted lines signify an inhibitory process. $4 E-B P 14 \mathrm{E}-$ binding protein 1

by which $\alpha$-LA exerts its multiple effects on beta cell function.

It can be argued that caution should be used when considering AMPK activators such as $\alpha$-LA and metformin for the treatment of diabetes; there appears to be a trade-off of increased insulin sensitivity for reduced insulin secretion. However, simultaneous activation of AMPK in canonical insulin-sensitive tissues and the beta cell in a physiological state may be beneficial, as improved insulin use is accompanied by a smaller demand for insulin production, which may protect beta cells from exhaustion. Furthermore, while AMPK-activating compounds are thought to exert negative effects on GSIS under standard culture conditions, several reports suggest that AMPK can be protective in beta cells under pathological conditions. Marchetti et al. [47] demonstrated that metformin restores beta cell function and prevents apoptosis in diabetic human islets, while others reported beneficial properties for AICAR in clonal beta cells under lipotoxic conditions [48]. Whether $\alpha$-LA behaves in a similar manner is an interesting possibility, especially if this compound would act as an antioxidant under these conditions.

In conclusion, our data reveal several novel pharmacological properties of $\alpha$-LA, including the inhibition of insulin secretion from rat islets, the perfused mouse pancreas and MIN6 cells. $\alpha$-LA also acts as a signalling molecule, activating AMPK and inhibiting p70 s6k and subsequently cell growth. $\alpha$-LA directly modulates the mitochondrial state via an acute increase in ROS production and depolarisation of the mitochondrial membrane. Our findings provide some insight into a possible explanation for the insulin-sensitising properties of $\alpha$-LA, which may occur in peripheral tissues in an AMPKdependent manner. Further studies on $\alpha$-LA and its relationship with AMPK are needed to gain a better 
understanding of the antidiabetic properties of this molecule and the precise mechanism by which AMPK regulation occurs.

Acknowledgements This work was supported by a research grant from the Canadian Institutes of Health Research (CIHR) to M.B. Wheeler (MOP-12898). M. B. Wheeler is a CIHR investigator. E. D. Targonsky is supported by a research scholarship from the Natural Sciences and Engineering Research Council of Canada. F. Dai is supported by a CIHR New Emerging Teams Grant in Diabetes Complications (NET-54012). We thank G. Bikopoulos for his assistance with islet isolations and A. Klip for her valuable advice regarding experimental design.

\section{References}

1. Lovell MA, Xie C, Xiong S, Markesbery WR (2003) Protection against amyloid beta peptide and iron/hydrogen peroxide toxicity by alpha lipoic acid. J Alzheimers Dis 5:229-239

2. Piotrowski P, Wierzbicka K, Smialek M (2001) Neuronal death in the rat hippocampus in experimental diabetes and cerebral ischaemia treated with antioxidants. Folia Neuropathol 39: 147-154

3. Mervaala E, Finckenberg P, Lapatto R et al (2003) Lipoic acid supplementation prevents angiotensin II-induced renal injury. Kidney Int 64:501-508

4. Midaoui AE, Elimadi A, Wu L, Haddad PS, de Champlain J (2003) Lipoic acid prevents hypertension, hyperglycemia, and the increase in heart mitochondrial superoxide production. Am J Hypertens 16:173-179

5. Bitar MS, Wahid S, Pilcher CW, Al Saleh E, Al Mulla F (2004) Alpha-lipoic acid mitigates insulin resistance in Goto-Kakizaki rats. Horm Metab Res 36:542-549

6. Khamaisi M, Potashnik R, Tirosh A et al (1997) Lipoic acid reduces glycemia and increases muscle GLUT4 content in streptozotocin-diabetic rats. Metabolism 46:763-768

7. Konrad T, Vicini P, Kusterer K et al (1999) alpha-Lipoic acid treatment decreases serum lactate and pyruvate concentrations and improves glucose effectiveness in lean and obese patients with type 2 diabetes. Diabetes Care 22:280-287

8. Konrad D, Somwar R, Sweeney G et al (2001) The antihyperglycemic drug alpha-lipoic acid stimulates glucose uptake via both GLUT4 translocation and GLUT4 activation: potential role of p38 mitogen-activated protein kinase in GLUT4 activation. Diabetes 50:1464-1471

9. Yaworsky K, Somwar R, Ramlal T, Tritschler HJ, Klip A (2000) Engagement of the insulin-sensitive pathway in the stimulation of glucose transport by alpha-lipoic acid in 3T3-L1 adipocytes. Diabetologia 43:294-303

10. Blumenthal SA (1984) Inhibition of gluconeogenesis in rat liver by lipoic acid. Evidence for more than one site of action. Biochem J 219:773-780

11. Hardie DG (2004) The AMP-activated protein kinase pathway-new players upstream and downstream. J Cell Sci 117:5479-5487

12. Shaw RJ, Kosmatka M, Bardeesy N et al (2004) The tumor suppressor LKB1 kinase directly activates AMP-activated kinase and regulates apoptosis in response to energy stress. Proc Natl Acad Sci U S A 101:3329-3335

13. Mu J, Brozinick JT Jr, Valladares O, Bucan M, Birnbaum MJ (2001) A role for AMP-activated protein kinase in contractionand hypoxia-regulated glucose transport in skeletal muscle. Mol Cell 7:1085-1094

14. Iglesias MA, Ye JM, Frangioudakis G et al (2002) AICAR administration causes an apparent enhancement of muscle and liver insulin action in insulin-resistant high-fat-fed rats. Diabetes 51:2886-2894
15. Minokoshi Y, Kim YB, Peroni OD et al (2002) Leptin stimulates fatty-acid oxidation by activating AMP-activated protein kinase. Nature 415:339-343

16. Yamauchi T, Kamon J, Minokoshi Y et al (2002) Adiponectin stimulates glucose utilization and fatty-acid oxidation by activating AMP-activated protein kinase. Nat Med 8: $1288-1295$

17. Zhou G, Myers R, Li Y et al (2001) Role of AMP-activated protein kinase in mechanism of metformin action. J Clin Invest 108:1167-1174

18. Kim MS, Park JY, Namkoong C et al (2004) Anti-obesity effects of alpha-lipoic acid mediated by suppression of hypothalamic AMP-activated protein kinase. Nat Med 10:727-733

19. Salt IP, Johnson G, Ashcroft SJ, Hardie DG (1998) AMPactivated protein kinase is activated by low glucose in cell lines derived from pancreatic beta cells, and may regulate insulin release. Biochem J 335:533-539

20. Da Silva Xavier G, Leclerc I, Salt IP et al (2000) Role of AMPactivated protein kinase in the regulation by glucose of islet beta cell gene expression. Proc Natl Acad Sci U S A 97: 4023-4028

21. Da Silva Xavier G, Leclerc I, Varadi A, Tsuboi T, Moule SK, Rutter GA (2003) Role for AMP-activated protein kinase in glucose-stimulated insulin secretion and preproinsulin gene expression. Biochem J 371:761-774

22. Tsuboi T, Da Silva Xavier G, Leclerc I, Rutter GA (2003) 5'AMP-activated protein kinase controls insulin-containing secretory vesicle dynamics. J Biol Chem 278:52042-52051

23. Wang X, Li H, De Leo D et al (2004) Gene and protein kinase expression profiling of reactive oxygen species-associated lipotoxicity in the pancreatic beta-cell line MIN6. Diabetes 53:129-140

24. Heron-Milhavet L, Haluzik M, Yakar S et al (2004) Musclespecific overexpression of CD36 reverses the insulin resistance and diabetes of MKR mice. Endocrinology 145:4667-4676

25. Koshkin V, Bikopoulos G, Chan CB, Wheeler MB (2004) The characterization of mitochondrial permeability transition in clonal pancreatic beta-cells. Multiple modes and regulation. J Biol Chem 279:41368-41376

26. Leclerc I, Woltersdorf WW, Da Silva Xavier G et al (2004) Metformin, but not leptin, regulates AMP-activated protein kinase in pancreatic islets: impact on glucose-stimulated insulin secretion. Am J Physiol Endocrinol Metab 286:E1023-E1031

27. Kefas BA, Cai Y, Kerckhofs K et al (2004) Metformin-induced stimulation of AMP-activated protein kinase in beta-cells impairs their glucose responsiveness and can lead to apoptosis. Biochem Pharmacol 68:409-416

28. Corton JM, Gillespie JG, Hawley SA, Hardie DG (1995) 5aminoimidazole-4-carboxamide ribonucleoside. A specific method for activating AMP-activated protein kinase in intact cells? Eur J Biochem 229:558-565

29. Scarlett JL, Sheard PW, Hughes G, Ledgerwood EC, Ku HH, Murphy MP (2000) Changes in mitochondrial membrane potential during staurosporine-induced apoptosis in Jurkat cells. FEBS Lett 475:267-272

30. Rowinsky EK (2004) Targeting the molecular target of rapamycin (mTOR). Curr Opin Oncol 16:564-575

31. Inoki K, Zhu T, Guan KL (2003) TSC2 mediates cellular energy response to control cell growth and survival. Cell 115:577-590

32. Brown EJ, Beal PA, Keith CT, Chen J, Shin TB, Schreiber SL (1995) Control of p70 s6 kinase by kinase activity of FRAP in vivo. Nature 377:441-446

33. Hara K, Yonezawa K, Kozlowski MT et al (1997) Regulation of eIF-4E BP1 phosphorylation by mTOR. J Biol Chem 272:26457-26463

34. Dicter N, Madar Z, Tirosh O (2002) Alpha-lipoic acid inhibits glycogen synthesis in rat soleus muscle via its oxidative activity and the uncoupling of mitochondria. J Nutr 132:3001-3006 
35. Maechler P, Wollheim CB (2001) Mitochondrial function in normal and diabetic beta-cells. Nature 414:807-812

36. Bernardi P, Scorrano L, Colonna R, Petronilli V, Di Lisa F (1999) Mitochondria and cell death. Mechanistic aspects and methodological issues. Eur J Biochem 264:687-701

37. Saris NE, Karjalainen A, Teplova VV, Lindros KO (1998) The stimulation of the mitochondrial permeability transition by dihydrolipoate and alpha-lipoate. Biochem Mol Biol Int 44:127-134

38. Lee WJ, Song KH, Koh EH et al (2005) Alpha-lipoic acid increases insulin sensitivity by activating AMPK in skeletal muscle. Biochem Biophys Res Commun 332:885-891

39. Lee WJ, Lee IK, Kim HS et al (2005) Alpha-lipoic acid prevents endothelial dysfunction in obese rats via activation of AMP-activated protein kinase. Arterioscler Thromb Vasc Biol 25:2488-2494

40. Richards SK, Parton LE, Leclerc I, Rutter GA, Smith RM (2005) Over-expression of AMP-activated protein kinase impairs pancreatic beta\}-cell function in vivo. J Endocrinol 187:225-235

41. Pende M, Kozma SC, Jaquet M et al (2000) Hypoinsulinaemia, glucose intolerance and diminished beta-cell size in S6K1deficient mice. Nature 408:994-997
42. Kneteman NM, Lakey JR, Wagner T, Finegood D (1996) The metabolic impact of rapamycin (sirolimus) in chronic canine islet graft recipients. Transplantation 61:1206-1210

43. Bell E, Cao X, Moibi JA et al (2003) Rapamycin has a deleterious effect on MIN-6 cells and rat and human islets. Diabetes 52:2731-2739

44. Paty BW, Harmon JS, Marsh CL, Robertson RP (2002) Inhibitory effects of immunosuppressive drugs on insulin secretion from HIT-T15 cells and Wistar rat islets. Transplantation 73:353-357

45. Um SH, Frigerio F, Watanabe M et al (2004) Absence of S6K1 protects against age- and diet-induced obesity while enhancing insulin sensitivity. Nature 431:200-205

46. Hawley SA, Pan DA, Mustard KJ et al (2005) Calmodulindependent protein kinase kinase-beta is an alternative upstream kinase for AMP-activated protein kinase. Cell Metab 2:9-19

47. Marchetti P, Del Guerra S, Marselli L et al (2004) Pancreatic islets from type 2 diabetic patients have functional defects and increased apoptosis that are ameliorated by metformin. J Clin Endocrinol Metab 89:5535-5541

48. Yamashita T, Eto K, Okazaki Y et al (2004) Role of uncoupling protein-2 up-regulation and triglyceride accumulation in impaired glucose-stimulated insulin secretion in a beta-cell lipotoxicity model overexpressing sterol regulatory elementbinding protein-1c. Endocrinology 145:3566-3577 